\title{
A study on residue levels of fungicides and insecticides applied according to the program of raspberry protection
}

\author{
Stanisław Sadło ${ }^{1}$ • Bartosz Piechowicz ${ }^{1}$ - Magdalena Podbielska ${ }^{1}$ - Ewa Szpyrka ${ }^{1,2}$
}

Received: 25 January 2017 / Accepted: 19 December 2017 / Published online: 6 January 2018

(C) The Author(s) 2018. This article is an open access publication

\begin{abstract}
This paper presents surveys on residue levels of fungicides and insecticides applied according to the raspberry protection program. The field trials were conducted in 2013-2014 on a plantation of raspberry of the Laszka variety dessert raspberry very popular in Poland. Laboratory samples were collected starting from a day of the first fruit picking to the end of harvest. The highest mean residue levels were found for boscalid and pyraclostrobin $(2.395 \mathrm{mg} / \mathrm{kg}$ and $0.732 \mathrm{mg} / \mathrm{kg}$, respectively), in both cases they were at a level of about $24 \%$ of their maximum residue levels (MRLs); and for cypermethrin $(0.235 \mathrm{mg} / \mathrm{kg}$; i.e. close to $50 \%$ of its MRL). The long-term dietary intakes of those substances by Polish adult consumers were also at low levels of 0.52 , 0.22 , and $0.04 \%$ of acceptable daily intake (ADI), respectively. Therefore, the results obtained indicated that even on day zero of picking ripe raspberries, the pesticide residues not only were well below their corresponding MRLs, but also their daily intakes did not even approach $1 \%$ of the ADI. In 2013, pesticide residues in ripe fruit evolved according to a pattern different than in a subsequent year; while in 2014 they changed at a constant exponential rate.
\end{abstract}

Keywords Dietary intake $\cdot$ Fungicide $\cdot$ Insecticide $\cdot$ Maximum residue levels $\cdot$ Raspberry $($ Rubus idaeus L.) $\cdot$ Residue levels

\section{Introduction}

Raspberries belong to berry fruit most frequently and most eagerly consumed by adults and children in Poland (Bobinaité et al. 2012) and frequently are eaten fresh without wash or processing. Our domestic production satisfies $20.1 \%$ of the global demand (Dmochowska 2012). Both leaves and roots of this plant are used in the production of tea, infusions and pharmaceuticals (Ryan et al. 2001; Holst et al. 2009). However, like some other crops, the raspberry plantations require a precise protection against pests and diseases (Graham and Jennings 2009; Mochecki 2014).

Responsible editor: Philippe Garrigues

Bartosz Piechowicz

bpiechow@poczta.onet.pl

1 Department of Analytical Chemistry, Institute of Biotechnology, University of Rzeszów, Pigonia 1 St, 35-310 Rzeszów, Poland

2 Laboratory of Pesticide Residue Analysis, Regional Experimental Station in Rzeszów, Institute of Plant Protection - National Research Institute, Langiewicza 28 St, 35-101 Rzeszów, Poland

\section{Raspberry pests and diseases}

Raspberries are susceptible to pests and to diseases caused by various fungal infections. A serious problem in Poland are also soil pests, especially grubs, including larvae of the widely widespread herbivorous May bug (Melolontha melolontha L.), a beetle from the Scarabaeidae family (Milenkovic and Stanisavljevic 2003; Totic 2014; Skrzecz et al. 2014; Sukovata et al. 2015). Other insects affecting raspberry crops are the raspberry beetle (Byturus tomentosus De Geer), the twospotted spider mite (Tetranychus urticae Koch), and the blossom weevil (Anthonomus rubi Herbst). The main raspberry diseases are grey mould (Botrytis cinerea Pers.), and antracnose (Gloeosporium Venetum Speg). Control of diseases of fungal origin requires a particular care and some knowledge about their sources. Unlike pests and weeds (which, generally, appear over one or two periods), pathogenic fungi may occur several times during the growing season. They also cause serious problems during store and transport of ripe fruit (Jennings 1982; Fox 2006; Faby 2008; O’Neill et al. 2012), as they change the taste and the appearance of raspberries, and they may also be a source of mycotoxins (Moss 2008; Mitchell et al. 2010). In those cases the protective effect is ensured by deposits of plant protection products 
(PPPs) present on the plant surface, mainly on leaves and fruit at a moment of possible infection. However, presence of residues of their active ingredients (AIs), required for the crop protection, is harmful to the health of consumers (Nolan et al. 1984; Fenske et al. 1990; Lee et al. 2004; Piechowicz et al. 2012; Piechowicz 2013). Regular research proves that raspberries may contain different and, very frequently, high residue levels of fungicides and insecticides (Sadło et al. 2007; Słowik-Borowiec et al. 2012; Szpyrka et al. 2015).

\section{Pesticide use in raspberry protection}

In Poland, systematic monitoring of the correctness of pesticide application in fruit and vegetables crops has been conducted since 1980s. Our first publications in this field concerned the determination of methidathion, deltamethrin and cypermethrin residues in hop cones, pesticide residues in greenhouse vegetables from south-eastern Poland, and the penetration of pesticides used in greenhouses to surface waters. The knowledge gathered during these surveys, as well as in the later period, forms a foundation for our opinion in this regard (Sadło 1990a, b; Sadło and Rupar 1990a, b; Szpyrka et al. 2008).

Recent studies have shown that nearly all raspberry samples contained residues of active ingredients of plant protection products, and quite frequently also so-called multiple residues. For example, in 2010-12, 42\% of the surveyed samples of raspberries contained pesticide residues; moreover, $4 \%$ of them exceeded the MRL (Szpyrka et al. 2015). The situation was similar in other years (Sadło et al. 2007; SłowikBorowiec et al. 2012). As apparent from other sources (Gnusowski et al. 2010), residues of some pesticides appeared also in fruit and leaves of raspberries produced using organic methods. All these observation imply there is a serious problem concerning the protection of raspberry plantations.

The supervised field trials conducted in 2013-2014 aimed at comprehensive studies on residues of fungicides and insecticides applied according to the raspberry protection program, determination of parameters of their exponential decomposition throughout the fruiting period, and the estimation of health risks for consumers. Additional aim was an estimation of the approximated relationship between the application rate and the residue level.

\section{Materials and methods}

\section{Field trials}

The supervised field trials were conducted at a commercial raspberry plantation (planted in 2012 and covering an area of $0.2 \mathrm{ha}$ ), which was protected against pests and diseases by plant protection products recommended in current programs (Table 1). The plantation was located in south-eastern
Poland, in the village Grabówka Kolonia, in the province of Lublin and was planted on brown soil. On the raspberry plantation, four rows of plants were chosen for the study, each approximately $150 \mathrm{~m}$ long. On each sampling date, laboratory samples (each of them consisting of 32 ripe raspberries picked from randomly selected plants) were collected from each of the selected rows. Sampling dates covered the period from the first day of fruit picking (June 28, 2013, and June 17, 2014), up to the end of fruit bearing (July 25, 2013, and July 15, 2014). In total, 40 laboratory samples were analysed.

Plant protection products (PPPs; see Table 1) were applied according to directions in their respective labels, which can be found on the website of the Ministry of Agriculture of Poland (Wyszukiwarka Środków Ochrony Roślin 2017).

In both years, laboratory samples were collected on five sampling dates, starting from the day of the first picking of ripe raspberries to the end of fruiting of the plantation, and then residues of folpet, tetraconazole, pyrimethanil, boscalid, pyraclostrobin, cyprodinil, azoxystrobin and difenoconazole (fungicides) as well of chlorpyrifos, $\lambda$-cyhalothrin, pirimicarb and cypermethrin (insecticides) were determined.

Chlorpyrifos, an organophosphorus insecticide (OP), is an AI in Dursban 480 EC, used against Melolontha melolontha L., Otiorhynchus sp. and Elateriadae sp. threatening raspberry plantations (Clark et al. 2012; Piechowicz et al. 2015). Dursban 480 EC acts by contact, ingestion and inhalation. In 2013 and 2014, this insecticide was applied to the soil at a dose of 21 per hectare ( $0.96 \mathrm{~kg}$ of chlorpyrifos per hectare), 44 and 34 days before the first crop picking, respectively.

Signum 33 WG (AIs: boscalid - a systemic compound from the anilides group, and pyraclostrobin-belonging to the strobilurin fungicides) is a plant protection product marketed in a form of water dispersible granules (WG) for preparing suspension of the working solution used for spraying raspberry plantations to control grey mould and raspberry spur blight, caused by Didymella applanata (Niessl), Leptosphaeria coniothyrium (Sacc.), Botrytis cinerea (Pers.) and Elsinoe veneta (Burkh.). As reported in Table 1, this fungicide was applied on June 28, 2013 (PHI: 0), and on June 30, 2014 (PHI; 18) at an application rate of $1.8 \mathrm{~kg} / \mathrm{ha}$, corresponding precisely to $0.4806 \mathrm{~kg}$ of boscalid and $0.1206 \mathrm{~kg}$ of pyraclostrobin per hectare. Moreover, Bellis 38 WG (AIs: $25.2 \% \mathrm{w} / \mathrm{w}$ boscalid and $12.8 \% \mathrm{w} / \mathrm{w}$ pyraclostrobin) was applied on June 17, 2013 (PHI: 11).

Mythos 300 SC (AI: pyrimethanil, a compound from the anilino-pyrimidines group) is a contact acting fungicide for preventive and interventional application to protect the raspberry plantation against grey mould caused by Botrytis cinerea (Pers.) (O’Neill et al. 2012), and withering of shoots caused by Didymella applanata (Niessl), Leptosphaeria coniothyrium (Sacc.), Botrytis cinerea (Pers.), Verticillium spp. and Fusarium spp. (Jennings 1982; Fox 2006; Faby 2008). This PPP was applied on June 10, 2013 (PHI: 18 days), 
Table 1 Spraying history: treatments dates for plant protection products (PPP), their active ingredients $(\mathrm{AI})$, application rates and pre-harvest intervals $(\mathrm{PHI})$

\begin{tabular}{|c|c|c|c|c|c|}
\hline \multirow[t]{2}{*}{ Treatments date } & \multirow[t]{2}{*}{$\begin{array}{l}\text { PPP, } \\
\text { Trade name }\end{array}$} & \multirow[t]{2}{*}{$\begin{array}{l}\text { AI, } \\
\text { Common name }\end{array}$} & \multicolumn{2}{|c|}{$\begin{array}{l}\text { Application rate } \\
{[\mathrm{kg} / \mathrm{ha} \text { or } \mathrm{L} / \mathrm{ha}]}\end{array}$} & \multirow[t]{2}{*}{ PHI [day] } \\
\hline & & & PPP & $\mathrm{AI}$ & \\
\hline \multicolumn{6}{|l|}{2013} \\
\hline May 15 & Dursban 480 EC* & Chlorpyrifos & 2.00 & 0.960 & 44 \\
\hline May 20 & Folpan $80 \mathrm{WG}$ & Folpet & 1.00 & 0.800 & 39 \\
\hline May 24 & Karate Zeon 050 SC & $\lambda$-cyhalothrin & 0.30 & 0.015 & 35 \\
\hline June 1 & Domark 100 EC & Tetraconazole & 0.50 & 0.050 & 27 \\
\hline June 10 & Mythos 300 SC & Pyrimethanil & 2.50 & 0.750 & 18 \\
\hline \multirow[t]{2}{*}{ June 17} & Bellis $38 \mathrm{WG}$ & Boscalid & 1.50 & 0.378 & 11 \\
\hline & & Pyraclostrobin & 1.50 & 0.192 & 11 \\
\hline June 21 & Pirimor $500 \mathrm{WG}$ & Pirimicarb & 0.75 & 0.375 & 7 \\
\hline June 24 & Cyperkill Super 250 EC & Cypermethrin & 0.15 & 0.038 & 4 \\
\hline June 25 & Unix $70 \mathrm{WG}$ & Cyprodinil & 0.50 & 0.350 & 3 \\
\hline \multirow[t]{2}{*}{ June 28} & Signum $33 \mathrm{WG}$ & Boscalid & 1.80 & 0.481 & 0 \\
\hline & & Pyraclostrobin & 1.80 & 0.121 & 0 \\
\hline June 28 & \multicolumn{5}{|c|}{ Date of first sampling/raspberry picking } \\
\hline \multicolumn{6}{|l|}{2014} \\
\hline \multirow[t]{2}{*}{ May 14} & Dursban 480 EC* & Chlorpyrifos & 2.00 & 0.960 & 34 \\
\hline & Cyperkil Super 250 EC & Cypermethrin & 0.15 & 0.038 & 34 \\
\hline June 14 & Mythos 300 SC & Pyrimethanil & 2.50 & 0.750 & 29 \\
\hline \multirow[t]{2}{*}{ June 23} & Amistar $250 \mathrm{SC}$ & Azoxystrobin & 0.50 & 0.125 & 25 \\
\hline & Score $250 \mathrm{SC}$ & Difenoconazole & 0.50 & 0.125 & 25 \\
\hline June 29 & Cyperkil Super 250 EC & Cypermethrin & 0.15 & 0.038 & 19 \\
\hline \multirow[t]{2}{*}{ June 30} & Signum $33 \mathrm{WG}$ & Boscalid & 1.80 & 0.481 & 18 \\
\hline & & Pyraclostrobin & 1.80 & 0.121 & 18 \\
\hline July 4 & Mythos $300 \mathrm{SC}$ & Pyrimethanil & 2.50 & 0.750 & 13 \\
\hline June 17 & \multicolumn{5}{|c|}{ Date of first sampling/raspberry picking } \\
\hline
\end{tabular}

PPP, plant protection product; AI, active ingredient

PHI (PreHarvest interval) - the time between the last application of a given PPP and harvesting of the treated crops *Product applied to soil
June 14 (PHI: 29 days), and July 4, 2014 (PHI: 13 days), at a dose of $0.75 \mathrm{~kg}$ of pyrimethanil per $1 \mathrm{ha}$, in all cases.

Unix 70 WG (AI: cyprodinil, a compound of anilinopyrimidine group) was used only once, on June 25, 2013, i.e., 3 days before the first raspberry picking, at a dose of $0.5 \mathrm{~kg}$ per hectare $(0.35 \mathrm{~kg}$ of the AI per hectare).

Folpan $80 \mathrm{WG}$ (AI: folpet, a contact acting compound from the phthalimides group), Domark 100 EC (AI: tetraconazole, a compound from the azole group), Amistar $250 \mathrm{SC}$ (AI: azoxystrobin, a compound from the strobilurines group), and Score 250 SC (AI: difenoconazole, a compound from the azole group) in the form of water dispersible granules (WG), emulsifiable concentrates (EC) and suspension concentrates (SC) were applied 39, 27, 25 and 25 days before the first picking, respectively.

Cyperkill Super 250 EC (AI: cypermethrin, a compound from the synthetic pyrethroids group) acts against insects by contact and by ingestion. When used at raspberry plantations, it controls Anthonomus rubi (Herbst) and aphids Amphorophora idaei (Börn) and Amphorophora rubi (Kalt.), pests commonly threatening raspberry crops (Kovanci et al. 2005; Borowiak-Sobkowiak 2006; Moss 2008). Cyperkill Super 250 EC was applied only once in 2013 (PHI: 4 days), and twice in 2014 (PHI: 34 and 19 days), at a dose of 0.151 per hectare $(0.0375 \mathrm{~kg}$ of AI per hectare), before the first crop picking.

Pirimor $500 \mathrm{WG}$ (AI: pirimicarb) is an insecticide used at the application rate of $0.75 \mathrm{~L}$ per hectare $(0.375 \mathrm{~kg}$ of pirimicarb per hectare), 7 days before the first raspberry picking. Pirimicarb, a fast-acting, selective aphicide belonging to the methyl carbamates group, is useful both against the organophosphate (OP)-resistant, and non-OP-resistant strains. It acts by contact, translaminar, by vapour, and has a systemic effect. It is used to protect a wide range of crops, including 
cereals, sugar beet, potatoes, fruit, and vegetables. It is relatively nontoxic to beneficial predators, parasites, and bees.

\section{Extraction procedure}

Analytical portions (consisting of 16 ripe raspberries) collected from the laboratory samples were homogenised in a blender (Waring Commercial 8010 EG) with $150 \mathrm{~mL}$ of acetone, and then the obtained homogenates were filtered (MN 640 DD) on a Büchner funnel under vacuum. The blender jar was flushed with $50 \mathrm{~mL}$ acetone, and the washings were used to wash the filter cake. 1/5 the volume (the equivalent of approx. $15 \mathrm{~g}$ of fruit) of the obtained filtrate was taken for the further analysis, and was placed in a separatory funnel together with $100 \mathrm{ml}$ of $2.5 \%$ sodium sulphate(VI) solution. Pesticide residues were extracted three times using, successively, 20, 10 and $10 \mathrm{ml}$ of dichloromethane. The combined extracts were evaporated to dryness, dissolved in approx. $10 \mathrm{~mL}$ of petroleum ether, and purified on a Florisil minicolumn (Valverde-Garcia et al. 1993). Pesticides were eluted with $70 \mathrm{~mL}$ of the ethyl ether-petroleum ether 3:7 (v/v) mixture, followed by $70 \mathrm{~mL}$ of the acetone-petroleum ether 1:9 ( $\mathrm{v} /$ v) mixture (Sadło et al. 2014; Sadło et al. 2015).

\section{Chromatographic analysis}

The final extracts were analysed by the Agilent 7890 gas chromatograph, equipped with the electron capture detector $(\mu \mathrm{ECD})$ and the nitrogen-phosphorus detector (NPD), and the fused silica column (HP-5 MS Ultra Inert column, 30-m length, $0.32-\mathrm{mm}$ i.d., and $0.25-\mu \mathrm{m}$ film thickness), operating in the splitless injection mode, connected to the NP (nitrogenphosphorus) and EC (electron capture) detectors using a universal Y-splitter. The temperature of the injector and the detectors was $250{ }^{\circ} \mathrm{C}$ and $300{ }^{\circ} \mathrm{C}$, respectively. The oven temperature was programmed as follows: $100{ }^{\circ} \mathrm{C}-0 \mathrm{~min} \rightarrow$ $10{ }^{\circ} \mathrm{C} / \mathrm{min} \rightarrow 180{ }^{\circ} \mathrm{C}-4 \mathrm{~min} \rightarrow 3{ }^{\circ} \mathrm{C} / \mathrm{min} \rightarrow 220{ }^{\circ} \mathrm{C}-$ $15 \mathrm{~min} \rightarrow 10{ }^{\circ} \mathrm{C} / \mathrm{min} \rightarrow 260{ }^{\circ} \mathrm{C}-11 \mathrm{~min}$; the total time of the analysis was $55.3 \mathrm{~min}$. Nitrogen (purity 6.0, flow $4.14 \mathrm{~mL} / \mathrm{min}$ ) was the carrier gas and the makeup gas for the $\mu \mathrm{ECD}(30 \mathrm{~mL} / \mathrm{min})$ and NPD $(10 \mathrm{~mL} / \mathrm{min})$. For the NPD, hydrogen and air flows were kept at $3 \mathrm{~mL} / \mathrm{min}$ and $60 \mathrm{~mL} /$ min, respectively.

The recovery studies were conducted by spiking analytical portions of raspberries with stock solutions of pesticides. The average recoveries of folpet, tetraconazole, pyrimethanil, boscalid, pyraclostrobin, cyprodinil, azoxystrobin and difenoconazole (fungicides) and of chlorpyrifos, $\lambda$ cyhalothrin, pirimicarb and cypermethrin (insecticides) were within the range of 85.7 to $118.1 \%$, with the relative standard deviations (RSDs) not exceeding $10.7 \%$ (for pyraclostrobin). The estimated limits of their quantification from ripe raspberries were $0.002 \mathrm{mg} / \mathrm{kg}$, and the limits of detection were
$0.001 \mathrm{mg} / \mathrm{kg}$. In addition to the in-house quality assurance programme, the Laboratory of Pesticide Residue Analysis of the Institute of Plant Protection successfully participated in international proficiency testing schemes confirmed by certificates.

\section{Data analysis}

The content/residue level $\left(\mathrm{R}_{\mathrm{i}}\right)$ of each substance in ripe raspberries was expressed as $\mathrm{mg} / \mathrm{kg}$. The mean values $\left(\mathrm{R}_{\mathrm{M}}\right)$, as well as the total residue levels of all substances (Tables 2 and 3 ) found in the four samples collected on each sampling date were calculated according to Eq. 1:

$R_{M}=\frac{1}{n} \sum_{i=1}^{n} R_{i}$

Where $i(1,2, \ldots, n=4)$ is the sample number, and $\mathrm{R}_{\mathrm{i}}$ represents the residue of a given substance, or the sum of residues of all substances, found in a given sample.

The residue of a given substance $\left(\mathrm{R}_{\mathrm{i}}\right)$ found in one of the four samples collected on a given sampling date, was divided by its respective maximum residue level (MRL), and then its mean percentage of the MRL was calculated using Eq. 2:

$\% \mathrm{MRL}=100 \sum_{i=1}^{n} \frac{R_{i}}{M R L}$

where $R_{\mathrm{i}}$ and MRL corresponded to the residue level of a given substance found in one of the four samples and to its legally accepted MRL in force in Poland in 2013-2014, respectively. The values of \%MRLs of all substances (so-called multiple residues) found in each of the four samples were summed up and then their total mean percentages of the respective MRL values were estimated.

Using the residue level of a given substance $\left(\mathrm{R}_{\mathrm{i}}\right)$, and assuming the body weight (b.w.) of $76 \mathrm{~kg}$, as well as a daily consumption (C) of raspberry by an adult Polish consumer of $0.007 \mathrm{~kg}$, the substance long-term dietary intake with ripe raspberries was calculated and expressed as \%ADI (Acceptable Daily Intake) (FAO 2009; Sadło et al. 2015), and then the mean percentages of respective ADI values for each of the four samples collected at sampling days were calculated. Similarly, assuming additive impact of various pesticides on the human organism, the total long-term daily intakes (in \%ADI) of all substances applied within the framework of plant protection program of the dessert raspberry plantation were calculated according to Eq. 3:

$\% \mathrm{ADI}=100 \frac{C}{\text { b.w. }} \sum_{i=1}^{n} \frac{R_{i}}{A D I}$

Finally, based on the calculated long-term daily intake of a given substance $\left(\mathrm{R}_{\mathrm{i}}\right)$ with ripe raspberries expressed as \% $\mathrm{ADI}$, 
Table 2 Presence of pesticide residues in ripe raspberries of the Laszka variety throughout a harvest period, 2013

Sampling date Chlorpyrifos Folpet Tetraconazole Pyrimethanil Pyraclostrobin Boscalid Pirimicarb Cypermethrin Cyprodinil Tota

\begin{tabular}{|c|c|c|c|c|c|c|c|c|c|c|c|}
\hline \multirow[t]{4}{*}{ June 28} & $R_{M}[\mathrm{mg} / \mathrm{kg}]$ & 0.002 & 0.003 & 0.013 & 0.182 & 0.732 & 2.395 & 0.369 & 0.111 & 0.314 & 4.121 \\
\hline & $\mathrm{SD}[\mathrm{mg} / \mathrm{kg}]$ & 0.001 & 0.002 & 0.003 & 0.054 & 0.203 & 0.683 & 0.104 & 0.057 & 0.054 & 0.734 \\
\hline & $\% \mathrm{MRL}$ & 0.4 & 0.0 & 6.6 & 1.8 & 24.4 & 23.9 & 18.4 & 22.3 & 3.1 & 101.0 \\
\hline & $\%$ ADI & 0.00 & 0.00 & 0.03 & 0.01 & 0.21 & 0.52 & 0.09 & 0.02 & 0.09 & 0.97 \\
\hline \multirow[t]{4}{*}{ July 4} & $R_{M}[\mathrm{mg} / \mathrm{kg}]$ & 0.002 & 0.006 & 0.004 & 0.010 & 0.088 & 0.236 & 0.050 & 0.009 & 0.138 & 0.545 \\
\hline & $\mathrm{SD}[\mathrm{mg} / \mathrm{kg}]$ & 0.001 & 0.004 & 0.002 & 0.014 & 0.033 & 0.160 & 0.028 & 0.006 & 0.052 & 0.218 \\
\hline & $\% \mathrm{MRL}$ & 0.4 & 0.1 & 2.1 & 0.1 & 2.9 & 2.4 & 2.5 & 1.9 & 1.4 & 13.8 \\
\hline & $\% \mathrm{ADI}$ & 0.00 & 0.00 & 0.01 & 0.00 & 0.03 & 0.05 & 0.01 & 0.00 & 0.04 & 0.14 \\
\hline \multirow[t]{4}{*}{ July 11} & $R_{M}[\mathrm{mg} / \mathrm{kg}]$ & 0.002 & 0.002 & 0.002 & 0.006 & 0.124 & 0.456 & 0.095 & 0.012 & 0.042 & 0.740 \\
\hline & $\mathrm{SD}[\mathrm{mg} / \mathrm{kg}]$ & 0.000 & 0.001 & 0.001 & 0.002 & 0.016 & 0.099 & 0.009 & 0.003 & 0.002 & 0.100 \\
\hline & $\% \mathrm{MRL}$ & 0.3 & 0.0 & 1.1 & 0.1 & 4.1 & 4.6 & 4.7 & 2.3 & 0.4 & 17.7 \\
\hline & $\% \mathrm{ADI}$ & 0.00 & 0.00 & 0.00 & 0.00 & 0.04 & 0.10 & 0.02 & 0.00 & 0.01 & 0.18 \\
\hline \multirow[t]{4}{*}{ July 18} & $R_{M}[\mathrm{mg} / \mathrm{kg}]$ & 0.002 & 0.004 & 0.004 & 0.014 & 0.164 & 0.484 & 0.062 & 0.008 & 0.031 & 0.773 \\
\hline & $\mathrm{SD}[\mathrm{mg} / \mathrm{kg}]$ & 0.001 & 0.005 & 0.000 & 0.003 & 0.032 & 0.084 & 0.023 & 0.002 & 0.015 & 0.126 \\
\hline & $\% \mathrm{MRL}$ & 0.5 & 0.4 & 2.0 & 0.1 & 5.5 & 4.8 & 3.1 & 1.5 & 0.3 & 17.9 \\
\hline & $\%$ ADI & 0.00 & 0.00 & 0.01 & 0.00 & 0.05 & 0.11 & 0.02 & 0.00 & 0.01 & 0.19 \\
\hline \multirow[t]{4}{*}{ July 25} & $R_{M}[\mathrm{mg} / \mathrm{kg}]$ & 0.002 & 0.007 & 0.004 & 0.004 & 0.168 & 0.457 & 0.066 & 0.004 & 0.008 & 0.719 \\
\hline & $\mathrm{SD}[\mathrm{mg} / \mathrm{kg}]$ & 0.000 & 0.009 & 0.003 & 0.002 & 0.110 & 0.257 & 0.046 & 0.004 & 0.002 & 0.419 \\
\hline & $\% \mathrm{MRL}$ & 0.5 & 0.1 & 2.0 & 0.0 & 5.6 & 4.6 & 3.3 & 0.8 & 0.1 & 16.9 \\
\hline & $\% \mathrm{ADI}$ & 0.00 & 0.00 & 0.01 & 0.00 & 0.05 & 0.10 & 0.02 & 0.00 & 0.00 & 0.18 \\
\hline
\end{tabular}

$\mathrm{R}_{\mathrm{M}}$, mean residues; $\mathrm{SD}$, standard deviation; MRL, maximum residue level; $\mathrm{ADI}$, acceptable daily intake

Table 3 Presence of pesticide residues in ripe raspberries of the Laszka variety throughout a harvest period, 2014

\begin{tabular}{|c|c|c|c|c|c|c|c|c|c|}
\hline \multicolumn{2}{|c|}{ Sampling date } & \multirow{2}{*}{$\begin{array}{l}\text { Chlorpyrifos } \\
0.002\end{array}$} & \multirow{2}{*}{$\begin{array}{l}\text { Pyraclostrobin } \\
0.047\end{array}$} & \multirow{2}{*}{$\frac{\text { Boscalid }}{1.196}$} & \multirow{2}{*}{$\begin{array}{l}\text { Cypermethrin } \\
0.235\end{array}$} & \multirow{2}{*}{$\begin{array}{l}\text { Difenoconazole } \\
0.016\end{array}$} & \multirow{2}{*}{$\begin{array}{l}\text { Azoxystrobin } \\
0.006\end{array}$} & \multirow{2}{*}{$\begin{array}{l}\text { Pyrimethanil } \\
0.148\end{array}$} & \multirow{2}{*}{$\begin{array}{l}\text { Total } \\
1.650\end{array}$} \\
\hline June 17 & $R_{M}[\mathrm{mg} / \mathrm{kg}]$ & & & & & & & & \\
\hline & $\mathrm{SD}[\mathrm{mg} / \mathrm{kg}]$ & 0.000 & 0.028 & 0.519 & 0.118 & 0.006 & 0.002 & 0.087 & 0.563 \\
\hline & $\% \mathrm{MRL}$ & 0.5 & 1.6 & 12.0 & 47.0 & 1.0 & 0.1 & 1.5 & 63.6 \\
\hline & $\% \mathrm{ADI}$ & 0.00 & 0.01 & 0.26 & 0.04 & 0.01 & 0.00 & 0.01 & 0.34 \\
\hline \multirow[t]{4}{*}{ June 25} & $R_{M}[\mathrm{mg} / \mathrm{kg}]$ & 0.002 & 0.030 & 0.744 & 0.123 & 0.009 & 0.003 & 0.035 & 0.949 \\
\hline & $\mathrm{SD}[\mathrm{mg} / \mathrm{kg}]$ & 0.001 & 0.007 & 0.326 & 0.084 & 0.002 & 0.001 & 0.003 & 0.367 \\
\hline & $\% \mathrm{MRL}$ & 0.4 & 1.0 & 7.4 & 24.7 & 0.6 & 0.1 & 0.4 & 34.6 \\
\hline & $\%$ ADI & 0.00 & 0.01 & 0.16 & 0.02 & 0.01 & 0.00 & 0.00 & 0.20 \\
\hline \multirow[t]{4}{*}{ July 2} & $R_{M}[\mathrm{mg} / \mathrm{kg}]$ & $0.001 *$ & 0.006 & 0.364 & 0.061 & 0.007 & 0.003 & 0.022 & 0.466 \\
\hline & $\mathrm{SD}[\mathrm{mg} / \mathrm{kg}]$ & 0.000 & 0.007 & 0.135 & 0.033 & 0.001 & 0.001 & 0.004 & 0.123 \\
\hline & $\% \mathrm{MRL}$ & 0.3 & 0.2 & 3.6 & 12.3 & 0.5 & 0.1 & 0.2 & 17.2 \\
\hline & $\% \mathrm{ADI}$ & 0.00 & 0.00 & 0.08 & 0.01 & 0.01 & 0.00 & 0.00 & 0.10 \\
\hline \multirow[t]{4}{*}{ July 8} & $R_{M}[\mathrm{mg} / \mathrm{kg}]$ & $0.001 *$ & 0.005 & 0.205 & 0.021 & 0.008 & 0.003 & 0.011 & 0.256 \\
\hline & $\mathrm{SD}[\mathrm{mg} / \mathrm{kg}]$ & 0.000 & 0.003 & 0.104 & 0.004 & 0.001 & 0.001 & 0.005 & 0.114 \\
\hline & $\% \mathrm{MRL}$ & 0.2 & 0.2 & 2.1 & 4.1 & 0.5 & 0.1 & 0.1 & 7.2 \\
\hline & $\%$ ADI & 0.00 & 0.00 & 0.04 & 0.00 & 0.01 & 0.00 & 0.01 & 0.06 \\
\hline \multirow[t]{4}{*}{ July 15} & $R_{M}[\mathrm{mg} / \mathrm{kg}]$ & $0.001 *$ & $0.000 *$ & 0.046 & 0.018 & 0.008 & 0.004 & 0.007 & 0.083 \\
\hline & $\mathrm{SD}[\mathrm{mg} / \mathrm{kg}]$ & 0.000 & 0.000 & 0.010 & 0.002 & 0.001 & 0.001 & 0.002 & 0.009 \\
\hline & $\%$ MRL & 0.1 & 0.0 & 0.4 & 3.6 & 0.5 & 0.1 & 0.1 & 4.9 \\
\hline & $\%$ ADI & 0.00 & 0.00 & 0.01 & 0.00 & 0.01 & 0.00 & 0.00 & 0.02 \\
\hline
\end{tabular}

$\mathrm{R}_{\mathrm{M}}$, mean residues; $\mathrm{SD}$, standard deviation; $\mathrm{MRL}$, maximum residue level; $\mathrm{ADI}$, acceptable daily intake

*Residue level below limit of determination 
and a daily raspberry consumption $(\mathrm{C}=0.007 \mathrm{~kg})$ by an adult Polish consumer, the safe consumption level of the fruit $\left(\mathrm{C}_{\text {safe }}\right.$ in $\mathrm{kg}$ ) could be easily calculated using Eq. 4:

$\mathrm{C}_{\mathrm{safe}}=100 \frac{C}{\% A D I}$

Decreasing trends for the mean residue levels expressed as $\mathrm{mg} / \mathrm{kg}$ and in \%MRL, as well as their daily intakes expressed as \% ADI were described by an exponential equation (Table 2) and by Figs. 3 and 4:

$\mathrm{R}_{\mathrm{t}}=R_{0} \times e^{-k t}$

where $\mathrm{R}_{0}$ and $\mathrm{R}_{\mathrm{t}}$ are the mean residue levels (also \%MRL or $\%$ ADI) of a given substance on day 0 and day $t$ after the first picking of ripe raspberries, respectively. MRL and ADI values were taken from the European Union Pesticides Database website (European Union Pesticides Database 2017).

\section{Rainfall analysis}

Rainfall measurements were performed using a mobile weather station WatchDog 2900ET (Spectrum Technologies, Inc. USA) located about $100 \mathrm{~m}$ from the raspberry plantation (Figs. 1 and 2).

\section{Results and discussion}

\section{Weather conditions}

The daily rainfall was measured throughout the harvest periods of harvest in 2013 and 2014 (Figs. 1 and 2, respectively). The rainfall has impact on boscalid and cypermethrin behaviour and, therefore, was considered in the discussion of results of these AIs. In the case of others AIs, there was no observed influence of rainfall on their dissipation rate.

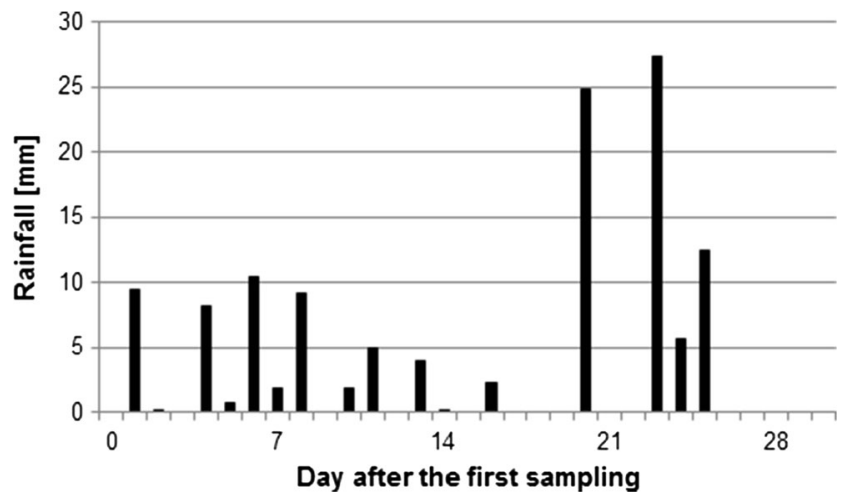

Fig. 1 Daily rainfall throughout the harvest period; 2013

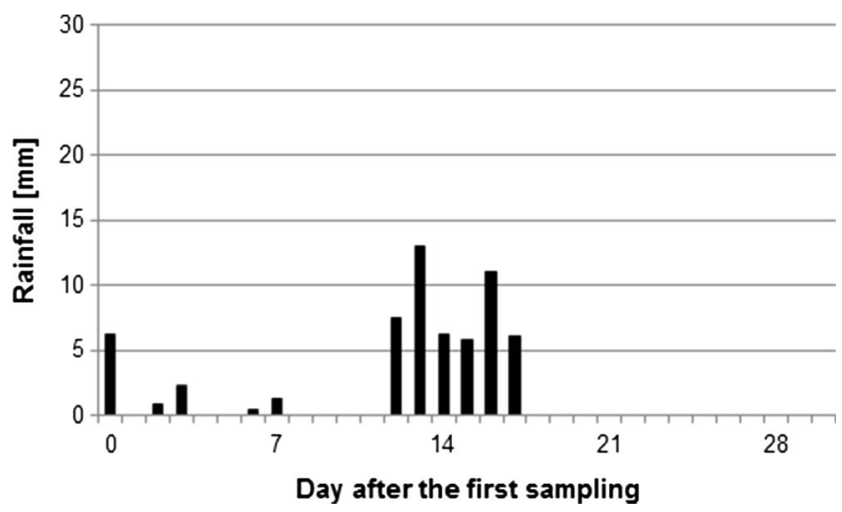

Fig. 2 Daily rainfall throughout the harvest period; 2014

\section{Fungicide residues in ripe raspberries}

The mean levels $\left(\mathrm{R}_{\mathrm{M}}\right)$ with relevant standard deviations (SD) were calculated for all AIs (fungicides: folpet, tetraconazole, pyrimethanil, boscalid, pyraclostrobin, cyprodinil, azoxystrobin and difenoconazole as well of insecticides: chlorpyrifos, $\lambda$-cyhalothrin, pirimicarb and cypermethrin) in ripe raspberries and are presented in Tables 2 and 3.

\section{Boscalid and pyraclostrobin residues}

In consequence of Bellis 38 WG (2013) and Signum 33 WG (2013 and 2014) treatments, on day zero of the ripe raspberries harvesting, the mean residues of boscalid amounted to $2.395 \mathrm{mg} / \mathrm{kg}(2013 ; 24.4 \%$ of MRL) and $1.196 \mathrm{mg} / \mathrm{kg}$ (2014; $12.0 \%$ of MRL), and were the highest of all ingredients. High levels of boscalid residues in ripe raspberries, especially in 2013, were not only a consequence of a relatively high application rate of Signum $33 \mathrm{WG}$, applied just before the first raspberry picking (PHI: 0), and the differences between its levels deposited on ripe raspberriesin 2013 and 2014 (Table 4), but also resulted from application of Bellis 38 WG 11 days before the first harvest.

In 2013, the boscalid residue levels found in ripe raspberry fruit evolved atypically. After their significant reduction, from 2.395 (the first sampling date) to $0.236 \mathrm{mg} / \mathrm{kg}$ (the second sampling date) during the first week of harvest, the mean residues remained at a similar level until the end of fruiting. The observed initial decline may be attributed to the rainfall, which occurred on July 29 and on August 1 and 3 (Fig. 1), disrupting an exponential $\left(R^{2}=0.2276\right)$ decreasing trend for residue levels.

On the other hand, in 2014, boscalid residues in ripe raspberry fruit decreased according to the exponential equation, $\mathrm{R}_{\mathrm{t}}=1.504 \mathrm{e}^{-0.112 \mathrm{t}}\left(R^{2}=0.9458\right)$, with a half-life slightly below 7 days, and in laboratory samples, collected during the last week of fruiting, were found to be at the mean level of $0.046 \mathrm{mg} / \mathrm{kg}$, which was still significantly above the standard for baby food of $0.01 \mathrm{mg} / \mathrm{kg}$ (Table 4). 
Table 4 Parameters of exponential disappearance trends for some pesticides used on a raspberry plantation in 2013 2014

\begin{tabular}{llllllll}
\hline Pesticide & $\begin{array}{l}\mathrm{R}_{0} \\
{[\mathrm{mg} / \mathrm{kg}]}\end{array}$ & $\begin{array}{l}\mathrm{k} \\
{[\text { day }]}\end{array}$ & $\mathrm{R}^{2}$ & $\begin{array}{l}\mathrm{t}_{\mathrm{R}=0.01} \\
{[\text { day }]}\end{array}$ & $\begin{array}{l}\mathrm{R}_{\mathrm{t}=7} \\
{[\mathrm{mg} / \mathrm{kg}]}\end{array}$ & $\begin{array}{l}\mathrm{t}_{1 / 2}=\ln 2 / \mathrm{k} \\
{[\text { day }]}\end{array}$ & $\begin{array}{l}\mathrm{MRL} \\
{[\mathrm{mg} / \mathrm{kg}]}\end{array}$ \\
\hline Boscalid, 2013 & 0.948 & 0.037 & 0.2276 & n.d. & n.d. & n.d. & 10 \\
Boscalid, 2014 & 1.504 & 0.112 & 0.9458 & 45 & 0.687 & 6.19 & 10 \\
Pyraclostrobin, 2013 & 0.296 & 0.033 & 0.2070 & n.d. & n.d. & n.d. & 3 \\
Pyraclostrobin, 2014 & 0.050 & 0.123 & 0.9053 & 13 & 0.021 & 5.64 & 3 \\
Cyprodinil, 2013 & 0.314 & 0.126 & 0.9758 & 27 & 0.130 & 5.50 & 10 \\
Pyrimethanil, 2013 & 0.064 & 0.107 & 0.6144 & 17 & 0.030 & 6.48 & 10 \\
Pyrimethanil, 2014 & 0.103 & 0.102 & 0.9392 & 23 & 0.051 & 6.80 & 10 \\
Pirimicarb, 2013 & 0.179 & 0.046 & 0.4086 & n.d. & n.d. & n.d. & 2 \\
Cypermethrin, 2013 & 0.051 & 0.097 & 0.7275 & 17 & 0.026 & 7.15 & 0.5 \\
Cypermethrin, 2014 & 0.232 & 0.099 & 0.9649 & 32 & 0.118 & 7.00 & 0.5 \\
Total residue of all AI, 2013 & 1.769 & 0.044 & 0.3460 & n.d. & n.d. & n.d. & - \\
Total residue of all AI, 2014 & 1.976 & 0.105 & 0.9741 & 50 & 0.948 & 6.6 & - \\
\hline
\end{tabular}

$\mathrm{R}_{0}$, initial pesticide concentration; $\mathrm{k}$, first-order constant rate; $R^{2}$, coefficient of determination; $\mathrm{t}_{\mathrm{R}=0.01}$, the time that must elapse until its residues reach the concentration level of $0.01 \mathrm{mg} / \mathrm{kg} ; \mathrm{R}_{\mathrm{t}=7}$, pesticide concentration after 7 days; $t_{1 / 2}$, half-life time; MRL, maximum residue level; n.d., not determined, due to lack of any correlation (poor fit), the parameters of exponential disappearance have not been determined
In 2013 and in 2014, on first days of raspberry picking, the mean pyraclostrobin residue levels (the other AI of Signum 33 WG and of Bellis $38 \mathrm{WG}$ ) amounted to $0.732 \mathrm{mg} / \mathrm{kg}$ (about $24.4 \%$ of its MRL) and $0.047 \mathrm{mg} / \mathrm{kg}$ (no more than $2 \%$ of the MRL), respectively. Similarly as in the case of boscalid residues, in 2013 initial pyraclostrobin residues were decreasing atypically, while in 2014 their decrease could be described by the exponential curve, $\left(R^{2}=0.9053\right)$, where $R_{0}=0.0501$, and $k=0.123$. It proves that the mean pyraclostrobin residue levels dropped by half within the first 6 days of crop picking, and the level of $0.01 \mathrm{mg} / \mathrm{kg}$ (10\% of the beginning amount) would have been achieved within 13 days.

Boscalid was studied by Chen and Zhang (2010) in strawberries, where it was applied at two dosages (349.5 and $525.0 \mathrm{~g} \mathrm{AI} / \mathrm{ha}$ ). The results showed that boscalid dissipation pattern followed the first-order kinetics with the half-lives of 4.9 and 6.4 days, respectively. The studies conducted by Jankowska et al. (2016) showed that the dissipation time for boscalid in tomatoes is 2.88 days for Marissa variety and 3.09 days for Harzfeuer variety. For the pyraclostrobin the dissipation time is 2.70 and 2.78 days for Marissa and Harzfeuer varieties, respectively.

\section{Pyrimethanil residues}

In 2013 and 2014, on day zero of raspberry picking, the mean pyrimethanil residues were at a level of 0.182 (PHI: 18 days) and $0.148 \mathrm{mg} / \mathrm{kg}$ (PHI: 13 days), respectively; thus, they were slightly below $2 \%$ of MRL. In both years, residue levels decreased significantly within the first weeks of the harvest. The exponential decline of the pyrimethanil residues in ripe fruit indicates clearly that their initial level dropped by half within 6-7 days and reached the level of $0.01 \mathrm{mg} / \mathrm{kg}$ after 17 and 23 days, respectively (see Table 4).

Szpyrka and Walorczyk (2013) reported that the dissipation time of pyrimethanil in different varieties of apples ranged from 11 to 22 days. Angioni et al. (2006) showed a half-life of 12 days for table grapes and 4.8 days for strawberries (Angioni et al. 2004).
Table 5 The mean mass of a single ripe raspberry throughout a harvest period; 2012-2014

\begin{tabular}{|c|c|c|c|c|c|c|}
\hline \multirow{2}{*}{$\begin{array}{l}\text { Sampling } \\
\text { term }\end{array}$} & \multicolumn{2}{|l|}{$2012 *$} & \multicolumn{2}{|l|}{2013} & \multicolumn{2}{|l|}{2014} \\
\hline & $\begin{array}{l}\text { Sampling } \\
\text { date }\end{array}$ & $\begin{array}{l}\text { Mean mass } \\
{[\mathrm{g}]}\end{array}$ & $\begin{array}{l}\text { Sampling } \\
\text { date }\end{array}$ & $\begin{array}{l}\text { Mean mass } \\
{[\mathrm{g}]}\end{array}$ & $\begin{array}{l}\text { Sampling } \\
\text { date }\end{array}$ & $\begin{array}{l}\text { Mean mass } \\
{[\mathrm{g}]}\end{array}$ \\
\hline No. 1 & June 19 & 5.3 & June 28 & 5.3 & June 17 & 6.1 \\
\hline No. 2 & June 26 & 5.9 & July 4 & 4.4 & June 25 & 6.3 \\
\hline No. 3 & July 3 & 4.1 & July 11 & 5.6 & July 2 & 6.5 \\
\hline No. 4 & July 10 & 4.8 & July 18 & 3.9 & July 8 & 5.8 \\
\hline No. 5 & July 17 & 3.8 & July 25 & 4.2 & July 15 & 5.4 \\
\hline
\end{tabular}

*(Sadło et al. 2014) 


\section{Cyprodinil residues}

Unix 70 WG (AI: cyprodinil) was applied in 2013. On day zero of raspberry picking, the mean cyprodinil residue was found to be at a level of $0.314 \mathrm{mg} / \mathrm{kg}$ (slightly above $3 \%$ of $M R L)$. This fungicide disappeared according to the exponential equation, $R_{t}=0.3143 \mathrm{e}^{-0.126 \mathrm{t}}$, and thus its mean residue levels decreased by half in about 5-6 days. Despite its fast disappearance $(k=0.126)$, the mean residue level of $0.01 \mathrm{mg} / \mathrm{kg}$ may be reached no earlier than in 4 weeks.

The dissipation half-life of cyprodinil on and in various plants is within the range of 2.3-16.7 days (PPDB 2017). The half-life of cyprodinil was 9.6-20.8 days (Zhang et al. 2015) in grapes, and in strawberries it reached 14.5 days under the field conditions- and 5.5 days under greenhouse conditions (Liu et al. 2011). In our earlier study on the disappearance of cyprodinil residues on tomato leaves, its half-life was 9 days (Szpyrka and Sadło 2009).

\section{Folpet, tetraconazole, azoxystrobin and difenoconazole residues}

Folpan 80 WG (AI: folpet), Domark 100 EC (AI: tetraconazole), Amistar $250 \mathrm{SC}$ (AI: azoxystrobin) and Score 250 SC (AI: difenoconazole) were applied 39, 27, 25 and 25 days before the first picking, respectively. Such prolonged PHIs, regardless of their application rates, generated only some trace residues of folpet, tetraconazole, azoxystrobin and difenoconazole in fruit, in the amount not exceeding $0.02 \mathrm{mg} / \mathrm{kg}$ just at the beginning of crop picking, so in practice, throughout the harvest, the ripe raspberries complied strictly to the standard for baby food of $0.01 \mathrm{mg} / \mathrm{kg}$.

\section{Insecticide residues in ripe raspberries}

\section{Cypermethrin residues}

Cyperkill Super 250 EC was applied only once in 2013 and twice in 2014. In 2013 and 2014, mean cypermethrin residues found on raspberries on first days of harvesting were at relatively high levels of 0.111 and $0.235 \mathrm{mg} / \mathrm{kg}$ (slightly above $22 \%$ and close to $47 \%$ of MRL, respectively). In 2013, those initial levels dropped significantly during the first week of the harvest (probably due to the rainfalls mentioned above), while in 2014 the residue level decreased strictly according to the exponential trend $\left(R^{2}=0.9649\right)$, and also dropped by half within 7 days, but during the whole harvesting period it remained at the level above $0.01 \mathrm{mg} / \mathrm{kg}$ (in 2014, there was only a slight rainfall; Fig. 2).

The dissipation half-life of cypermethrin on and in various plant is within the range of 1.2-10.3 days (PPDB 2017). In our study, this value in raspberry fruits was equal to 7.15 days in 2013 and 7.00 days in 2014 (Table 4). In our earlier study, half-lives of cypermethrin in raspberry fruits and leaves were 8 and 16 days, respectively (Sadło et al. 2014).

\section{Pirimicarb residues}

In 2013, Pirimor 500 WG (AI: pirimicarb) was applied 7 days before the first raspberry picking. The mean pirimicarb residue in ripe raspberry fruit was found to be at a relatively high level of $0.369 \mathrm{mg} / \mathrm{kg}$, corresponding to $18.4 \%$ of MRL. Within the first week of fruiting, its residue dropped significantly, and, on average, was equal to $0.05 \mathrm{mg} / \mathrm{kg}$. However, despite its initial significant decrease, the final residue level was still significantly above $0.01 \mathrm{mg} / \mathrm{kg}$.

With its half-life of 4.9 days (PPDB 2017), pirimicarb is not persistent on a plant. In a study on its disappearance in apples, its half-lives were equal to 4 days and 11 days on leaves and fruits, respectively (Machowska and Sadło 2009).

\section{Chlorpyrifos residues}

In 2013 and 2014, the insecticide Dursban 480 EC (AI: chlorpyrifos) was applied to the brown soil 44 and 34 days before the first crop picking, respectively.

In our earlier studies conducted in 2012, residues of this compound were still detected at the level of $0.007 \pm$ $0.0007 \mathrm{mg} / \mathrm{kg}$ in soil samples collected 6 weeks after the treatment (Sadło et al. 2014). In 2014, immediately after the treatment, the mean chlorpyrifos residue level in the $0-20 \mathrm{~cm}$ soil layer was $0.12 \mathrm{mg} / \mathrm{kg}$, dissipating in accordance with the exponential equation, $\mathrm{R}_{\mathrm{t}}=0.116 \mathrm{e}^{-0.052 \mathrm{t}}\left(R^{2}=0.878\right)$, and during the last week of the pre-harvest interval (PHI: 33 days) it was still at the level of $0.004 \mathrm{mg} / \mathrm{kg}$. Chlorpyrifos half-lives in soils vary within the range of 1-100 days (Fang et al. 2006). Additionally, the low water solubility $\left(1.4 \mathrm{mg} \mathrm{L}^{-1}\right)$ and high $\log \mathrm{K}_{\mathrm{ow}}$ (4.7) values of this AI may result in insignificant mobility in soil (Min et al. 2009; MacBean 2012; IUPAC 2017). Therefore, it is likely that chlorpyrifos residues in arable soils are exposed to plant uptake (Hwang et al. 2017).

Throughout the period of harvesting, chlorpyrifos residues in ripe raspberries did not exceed $0.01 \mathrm{mg} / \mathrm{kg}$, similarly as in 2012 (Sadło et al. 2015). Therefore, not only they were well below MRL $(0.5 \mathrm{mg} / \mathrm{kg})$ established for raspberry intended for adults, but also significantly below the level of $0.01 \mathrm{mg} /$ $\mathrm{kg}$, established for baby food.

\section{Total pesticide residues (sum of fungicide and insecticide residues) in ripe raspberries}

In 2013, ripe raspberries collected for the analysis on day zero of the picking contained residues of eight AIs of PPPs (multiple residues). Their mean total content was found to be at a relatively high level of $4.121 \pm 0.734 \mathrm{mg} / \mathrm{kg}$, which, according to Eq. 1, corresponded to $101.0 \%$ of the respective MRLs, and 
was about two times higher than those found in 2014 (see Table 2) and 2012 (Sadło et al. 2014; Sadło et al. 2015). The total content of the compounds found in the samples collected on subsequent sampling dates was significantly lower, and their residues decreased at similar rates as observed for boscalid, pyraclostrobin, cypermethrin or pyrimethanil, although their final mean residues still amounted to $0.719 \mathrm{mg} /$ $\mathrm{kg}$, i.e. significantly above $0.01 \mathrm{mg} / \mathrm{kg}$.

In 2014, on the day zero of the picking, raspberry samples contained seven AIs of PPPs but their total residues were significantly lower than those found a year before (Table 3), and reached the mean level of $1.650 \pm 0.563 \mathrm{mg} / \mathrm{kg}$, corresponding to only $63.6 \%$ of MRL. In the subsequent weeks of the plantation fruiting, the total residues decreased exponentially $\left(\mathrm{R}_{\mathrm{t}}=64.118 \mathrm{e}^{-0.096 \mathrm{t}}, R^{2}=0.9908\right)$ (Fig. 3), and finally reached the level of $0.083 \mathrm{mg} / \mathrm{kg}$, also significantly exceeding $0.01 \mathrm{mg} / \mathrm{kg}$.

\section{Pesticide residues in ripe raspberries vs. pesticide application rates}

The estimation of a relationship between the pesticide application rate and the residue level is not easy for several reasons. First, the treatments were performed when the fruit was at various stages of maturity. A clear correlation between a radius, a surface area and a volume of an individual raspberry fruit indicates that, for the same application rate of the active ingredient, smaller fruit should contain higher residue levels, when they are expressed as $\mathrm{mg} / \mathrm{kg}$. Second, the same PPPs were applied at different PHIs and, therefore, their deposits were subject to the influence of different weather conditions. Third, with the development of the bushes, not only the area of leaves (the canopy impact) increases, but also an area and properties of fruit surface vary. Finally, very frequently the pesticide is applied repeatedly, as it was in 2013, when Signum 33 WG (PHI: 0 days) was applied after Bellis 38 WG application

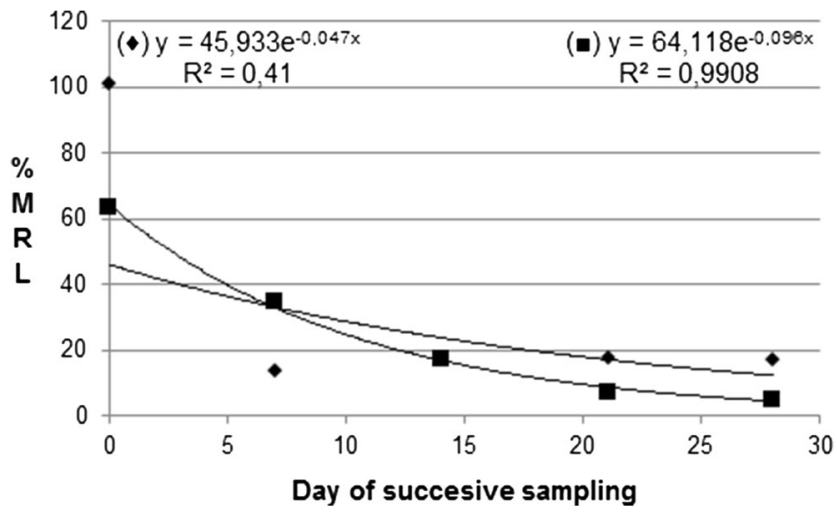

Fig. 3 Exponential disappearances of total residues expressed as \%MRL (maximum residue levels) throughout the harvest period in 2013 ( $\downarrow$ ) and $2014(\mathbf{\square})$
(PHI: 11 days), and thus, the mean boscalid residue resulted from both treatments.

Despite the above, using the mean levels of boscalid residues detected in 2013-2014, we approximately estimated a relationship between the level of residues and the application rate (D; dose). This relationship shows that immediately after the application of any substance at a dose of $1 \mathrm{~kg} / \mathrm{ha}$, its residue levels in ripe raspberries should be within the range of 2.4917 to $4.9896 \mathrm{mg} / \mathrm{kg}$ (Table 6), and the mean level should be approximately $3.6 \mathrm{mg} / \mathrm{kg}$. This rough estimate can indicate that the current MRLs are significantly overestimated and consequently are not a good tool for assessing the correctness of actions conducted to protect a plantation.

\section{Long-term dietary intakes of pesticide residues with ripe raspberries}

Generally, long-term dietary intakes are calculated by multiplying mean residues obtained from supervised field trials by an average daily consumption per capita estimated for each commodity and expressed as a percentage of the ADI (FAO 2009). When the intake exceeds (is equal to or above $100 \%$ of ADI) the ADI level, the result may be interpreted as giving rise to a health concern.

In our study, we decided to base our calculations on the individual pesticide residue levels found in a given sample, assuming body weight (b.w.) of $76 \mathrm{~kg}$ and a daily consumption of raspberries by an adult Polish consumer equal to $0.007 \mathrm{~kg}(\mathrm{C})$. Thus, to calculate the long-term dietary intake of a given substance (and its average level) with ripe fruit, four samples were collected for the analysis on each of five sampling dates. The highest daily intake was possible for boscalid (the average: $0.52 \%$ of its ADI), followed by pyraclostrobin (the average: $0.21 \%$ of its ADI) and pirimicarb (the average: $0.09 \%$ of its ADI) in 2013, and for boscalid (the average: $0.26 \%$ of its ADI), followed by cypermethrin (the average: $0.04 \%$ of its ADI) in 2014 (Fig. 4).

Moreover, assuming an additive effect of pesticide residues on a human body, the long-term daily intake of all substances (generating so-called multiple residues) applied within the framework of the plant protection program for a raspberry plantation, was calculated for each of four samples according to Eq. 2, and its mean values are shown in Tables 2 and 3. In 2013, the average long-term daily intake of all substances was $0.97 \%$ of their ADIs. During the first week, it decreased below $0.2 \%$ of the ADI and then remained at the constant level to the end of fruiting, while in 2014, the average long-term daily intake of all substances was $0.34 \%$ of their ADI, and then decreased exponentially $\left(R^{2}=0.9836\right)$, reaching its final value of $0.02 \%$ of ADI. Generally, in both years, the average longterm daily intakes were substantially below the acceptable daily intake and they should not cause any chronic health risk for an adult consumer. 
Table 6 An approximate relationship between a dose of an active ingredient in Signum 33 WG and its residue in ripe raspberries on the example of boscalid residues detected in 2012-2014

\begin{tabular}{lllllc}
\hline Year & AI common name & $\begin{array}{l}\text { D of AI } \\
{[\mathrm{kg}]}\end{array}$ & $\begin{array}{l}\mathrm{R} \\
{[\mathrm{mg} / \mathrm{kg}]}\end{array}$ & Regression equation & $\begin{array}{l}\text { PHI } \\
{[\text { day] }}\end{array}$ \\
\hline $2012^{*}$ & Boscalid & 0.48 & 0.950 & $R=1.9792 \times \mathrm{D}$ & 6 \\
2013 & Boscalid & 0.48 & 2.395 & $R=4.9896 \times \mathrm{D}$ & 0 \\
2014 & Boscalid & 0.48 & 1.196 & $R=2.4917 \times \mathrm{D}$ & 18 \\
\hline
\end{tabular}

AI, active ingredient; D of AI, dose of active ingredient; R, pesticide residue; PHI, PreHarvest Interval

*(Sadło et al. 2014)

\section{Safe daily consumption of ripe raspberries with residues of pesticides used in field trials in 2013-2014}

Safe daily consumption of ripe raspberries can easily be calculated using Eq. 4. The highest total long-term dietary intake, equal to $0.97 \% \mathrm{ADI}$, indicates that, the safe level of raspberry consumption for an adult consumer exceeded $700 \mathrm{~g}$ a day over a lifetime, without any appreciable health risk in 2013, and exceeded even $2000 \mathrm{~g}$ in 2014 . Moreover, taking into account that Acute Reference Dose (ARfD) for each of the studied substances is about 5 times higher than the respective Acceptable Daily Intake (ADI), the raspberry fruit from Poland is completely safe for the consumer.

\section{Conclusions}

In 2013-2014, supervised field trials were conducted on commercial raspberry plantations. Obtained results clearly indicated that residues of the individual active ingredients of plant protection products in ripe fruit occurred at different levels, depending on an application rate and a PHI, i.e. the period that elapsed from the day of their application to day zero of fruit picking. In conclusion, therefore:

- the highest mean residue levels in ripe raspberries were found for boscalid and pyraclostrobin (2.395 and

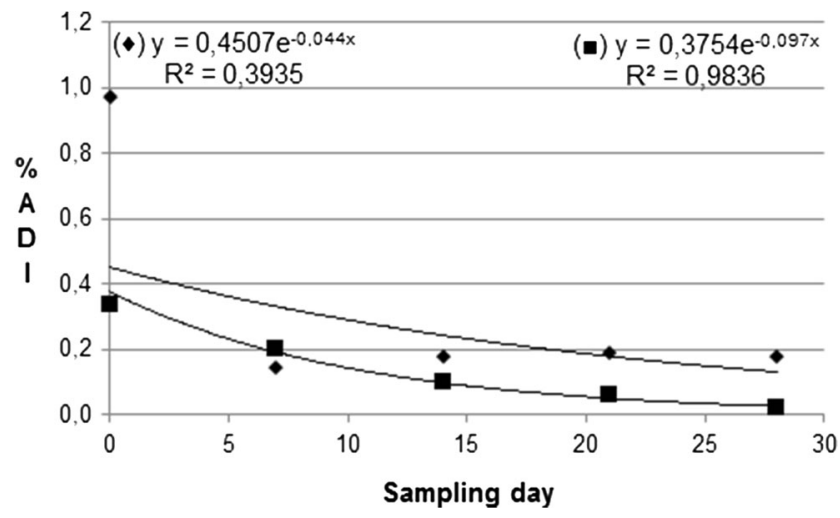

Fig. 4 Exponential changes of the total long-term dietary intakes expressed as \%ADI (acceptable daily intake) throughout the harvest period in $2013(\bullet)$ and 2014 (匹)
$0.732 \mathrm{mg} / \mathrm{kg}$ ), in both cases they were at the level of about $24 \%$ of their MRLs, and for cypermethrin $(0.235 \mathrm{mg} / \mathrm{kg}$; i.e., close to $50 \%$ of its MRL),

- the long-term dietary intake of those substances by a Polish adult consumer was also at low levels of $0.52 \%$, $0.22 \%$, and $0.04 \%$ of ADI, respectively,

- the obtained results indicate that even on the day zero of fruiting the pesticide residues in ripe raspberries not only were well below the corresponding MRLs, but their daily intakes did not even approach $1 \%$ of the ADI,

- the residues of folpet, tetraconazole, azoxystrobin and difenoconazole, applied 39, 27, 25 and 25 days before the first fruit picking, respectively, residues of chlorpyrifos applied to the soil, and residues of pyraclostrobin, pyrimethanil and cypermethrin in the raspberry fruit picked in the third decade of harvest, were below or equal to $0.01 \mathrm{mg} / \mathrm{kg}$,

- to produce the raspberries with the residue level below or equal to $0.01 \mathrm{mg} / \mathrm{kg}$, it would be necessary to terminate the application of pesticides at least 2-3 weeks before the first crop picking and to ensure that a preparation efficient at low doses, for instance Domark 100 EC or Nissorun $050 \mathrm{EC}$, is applied as the last treatment,

- in 2013, pesticide residues in ripe fruit evolved according to a different pattern than in the subsequent year, while in 2014 they decreased exponentially at constant exponential rates ranging from 0.099 (cypermethrin) to 0.123 (pyraclostrobin).

Open Access This article is distributed under the terms of the Creative Commons Attribution 4.0 International License (http:// creativecommons.org/licenses/by/4.0/), which permits unrestricted use, distribution, and reproduction in any medium, provided you give appropriate credit to the original author(s) and the source, provide a link to the Creative Commons license, and indicate if changes were made.

\section{References}

Angioni A, Schirra M, Garau VL, Melis M, Tuberoso CI, Cabras P (2004) Residues of azoxystrobin, fenhexamid and pyrimethanil in strawberry following field treatments and the effect of domestic washing. Food Addit Contam 21(11):1065-1070. https://doi.org/10.1080/ 02652030400010066 
Angioni A, Sarais G, Dedola F, Caboni P (2006) Pyrimethanil residues on table grapes Italia after field treatment. J Environ Sci Health B 41(6): 833-841. https://doi.org/10.1080/03601230600805881

Bobinaité R, Viškelis P, Venskutonis PR (2012) Variation of total phenolics, anthocyanins, ellagic acid and radical scavenging capacity in various raspberry (Rubus spp.) cultivars. Food Chem 132(3):14951501. https://doi.org/10.1016/j.foodchem.2011.11.137

Borowiak-Sobkowiak B (2006) Bionomy and ecology of Amphorophora idaei (Börn.) on raspberry. J Plant Prot Res 46:169-180

Chen L, Zhang S (2010) Dissipation and residues of boscalid in strawberries and soils. Bull Environ Contam Toxicol 84(3):301-304. https://doi.org/10.1007/s00128-010-9934-y

Clark KE, Hartley SE, Brennan RM, Jennings SN, McMenemy LS, McNicol JW, Mitchell C, Johnson SN (2012) Effects of cultivar and egg density on a colonizing vine weevil (Otiorhynchus sulcatus) population and its impacts on red raspberry growth and yield. Crop Prot 32:76-82. https://doi.org/10.1016/j.cropro.2011.10.008

Dmochowska H (2012) Statistical yearbook of the Republic of Poland, Central Statistical Office. http://stat.gov.pl/cps/rde/xbcr/gus/SY statistical_yearbook of Poland_2012.pdf. Accessed 2 May 2014

European Union Pesticides Database website. http://ec.europa.eu/sanco pesticides/public/?event=activesubstance. selection\&language $=\mathrm{EN}$. Accessed 20 Jan 2017

Faby R (2008) Control of cane diseases in raspberries. Acta Hortic 777:323

Fang H, Yu YL, Wang X, Shan M, Wu XM, Yu JQ (2006) Dissipation of chlorpyrifos in pakchoi-vegetated soil in a greenhouse. J Environ Sci (China) 18(4):760-764

FAO (Food and Agriculture Organization of the United Nations) (2009) Pesticide Residues Submission and evaluation of pesticide residues data for the estimation of maximum residue levels in food and feed FAO Plant Production and Protection 197. http://www.fao.org/ docrep/012/i1216e/11216e.pdf. Accessed 21 Jan 2017

Fenske RA, Black KG, Elkner KP, Lee CL, Methner MM, Soto R (1990) Potential exposure and health risks of infants following indoor residential pesticide applications. Am J Public Health 80(6):689-693. https://doi.org/10.2105/AJPH.80.6.689

Fox RTV (2006) Spur blight of raspberry. Mycologist 20(2):77. https:// doi.org/10.1016/j.mycol.2006.03.002

Gnusowski B, Nowacka A, Walorczyk S, Łozowicka B, Szpyrka E, Sadło S (2010) Pesticide residues in organic food of plant origin in Poland in 2009. Prog Plant Prot 50:1903-1909

Graham J, Jennings J (2009) Raspberry breeding. In: Mohan S, Priyadarshan PM (eds) Breeding plantation tree crops: temperate species. Springer-Verlag, New York, pp 233-248. https://doi.org/ 10.1007/978-0-387-71203-1 7

Holst L, Haavik S, Nordeng H (2009) Raspberry leaf - should it be recommended to pregnant women? Complement Ther Clin Pract 15(4):204-208. https://doi.org/10.1016/j.ctcp.2009.05.003

Hwang JI, Lee SE, Kim JE (2017) Comparison of theoretical and experimental values for plant uptake of pesticide from soil. PLoS One 12(2):e0172254. https://doi.org/10.1371/journal.pone.0172254

IUPAC (International Union of Pure and Applied Chemistry) (2017) Pesticide properties database. http://sitem.herts.ac.uk/aeru/iupac/ Reports/154.htm. Accessed 1 Nov 2017

Jankowska M, Kaczynski P, Hrynko I, Łozowicka B (2016) Dissipation of six fungicides in greenhouse-grown tomatoes with processing and health risk. Environ Sci Pollut Res 23(12):11885-11900. https://doi.org/10.1007/s11356-016-6260-x

Jennings DL (1982) Resistance to Didymella applanata in red raspberry and some related species. Ann Appl Biol 101(2):331-337. https:// doi.org/10.1111/j.1744-7348.1982.tb00829.x

Kovanci OB, Kovanci B, Gencer NS (2005) Sampling and development of economic injury levels for Anthonomus rubi Herbst adults. Crop Prot 24(12):1035-1041. https://doi.org/10.1016/j.cropro.2005.02.007

Lee WJ, Blair A, Hoppin JA, Lubin JH, Rusiecki JA, Sandler DP, Dosemeci M, Alavanja MC (2004) Cancer incidence among pesticide applicators exposed to chlorpyrifos in the agricultural health study. J Natl Cancer Inst 96(23):1781-1789. https://doi.org/ 10.1093/jnci/djh324

Liu C, Wang S, Li L, Ge J, Jiang S, Liu F (2011) Dissipation and residue of cyprodinil in strawberry and soil. Bull Environ Contam Toxicol 86(3):323-325. https://doi.org/10.1007/s00128-011-0216-0

MacBean C (ed) (2012) The pesticide manual. $16^{\text {th }}$ ed. Alton, Hampshire, pp 199-201

Machowska A, Sadło S (2009) Disappearance of pirimicarb residues in fruits and leaves of Jonagold variety. Prog Plant Prot 49:1435-1439

Milenkovic S, Stanisavljevic M (2003) Raspberry pests in Serbia. IOBCWPRS Bull 26:23-28

Min ZW, Kim TH, Shin JH, Lee SM, Kim JE (2009) Accelerated effect of ferric salts on degradation of thiophosphate fungicide, tolclofosmethyl by zerovalent iron. J Korean Soc Appl Biol Chem 52(6): 681-687. https://doi.org/10.3839/jksabc.2009.113

Mitchell C, Johnson SN, Gordon SC, Nicholas A, Birch E, Hubbard SF (2010) Combining plant resistance and a natural enemy to control Amphorophora idaei. BioControl 55(3):321-327. https://doi.org/10. 1007/s10526-009-9257-2

Mochecki J (2014) Metodyka integrowanej produkcji malin. Państwowa Inspekcja Ochrony Roślin i Nasiennictwa, Warszawa https://piorin. gov.pl/download/gfx/piorin/pl/defaultstronaopisowa/1328/1/1/ip_ maliny_ed_3.pdf. Accessed 1 November 2017

Moss MO (2008) Fungi, quality and safety issues in fresh fruit and vegetables. J Appl Microbiol 104(5):1239-1243. https://doi.org/10. 1111/j.1365-2672.2007.03705.x

Nolan RJ, Rick DL, Freshour NL, Saunders JH (1984) Chlorpyrifos: pharmacokinetics in human volunteers. Toxicol Appl Pharmacol 73(1):8-15. https://doi.org/10.1016/0041-008X(84)90046-2

O’Neill T, Wedgwood E, Berrie AM, Allen J, Xu X (2012) Managing grey mould on raspberry grown under protection without use of fungicides during flowering and fruiting. Agron Sustain Dev 32(3):673-682. https://doi.org/10.1007/s13593-011-0063-8

Piechowicz B (2013) Impact of the use of pesticides on children's health. Bezpieczeństwo Pracy 13:22-24 [in Polish]

Piechowicz B, Stawarczyk K, Stawarczyk M (2012) Hazard posed by using chemicals for plant protection. Bezpieczeństwo Pracy 3:5-7 [in Polish]

Piechowicz B, Sadło S, Sałaciak E (2015) Toksykologiczne aspekty doglebowego stosowania preparatu Dursban 480 EC w uprawie maliny deserowej. VI ${ }^{\text {th }}$ Conference: Bezpieczeństwo Pracy Środowisko Zarządzanie, Szczyrk, pp 195-204 [in Polish]

PPDB (Pesticide Properties Data Base) (2017). https://sitem.herts.ac.uk/ aeru/ppdb/en/index.htm. Accessed 1 Nov 2017

Ryan T, Wilkinson JM, Cavanagh HMA (2001) Antibacterial activity of raspberry cordial in vitro. Res Vet Sci 71(3):155-159. https://doi. org/10.1053/rvsc.2001.0502

Sadło S (1990a) Metoda oznaczania pozostałości metydationu, deltametryny i cypermetryny w szyszkach chmielu. Prace Naukowe Instytutu Ochrony Roślin 31:149-155 [in Polish]

Sadło S (1990b) Pozostałości niektórych fungicydów w ogórkach gruntowych $\mathrm{z}$ terenu południowo - wschodniej Polski w latach 1987-1989. Prace Naukowe Instytutu Ochrony Roślin 32:135-141 [in Polish]

Sadło S, Rupar J (1990a) Badania w zakresie występowania pozostałości pestycydów w uprawach szklarniowych na terenie południowowschodniej Polski. Prace Naukowe Instytutu Ochrony Roślin 31: 141-149 [in Polish]

Sadło S, Rupar J (1990b) Przenikanie pestycydów stosowanych w uprawach szklarniowych do wód powierzchniowych. Prace Naukowe Instytutu Ochrony Roślin 32:129-134 [in Polish]

Sadło S, Szpyrka E, Rogozińska K, Rupar J, Kuźmienko A (2007) Występowanie pozostałości pestycydów w malinach w latach 2000-2005. Roczniki PZH 58:509-513 [in Polish] 
Sadło S, Szpyrka E, Stawarczyk M, Piechowicz B (2014) Behavior of pyrimethanil, pyraclostrobin, boscalid, cypermethrin and chlorpyrifos residues on raspberry fruit and leaves of Laszka variety. J Environ Sci Health B 49(3):159-168. https://doi.org/10.1080/ 03601234.2014 .858005

Sadło S, Szpyrka E, Piechowicz B, Grodzicki P (2015) A case study on toxicological aspects of the pest and disease control in the production of the high-quality raspberry (Rubus idaeus L.) J Environ Sci Health B 50(1):8-14. https://doi.org/10.1080/03601234.2015.964136

Skrzecz I, Sowińska A, Janiszewski W (2014) Effects of botanical antifeedants on Melolontha melolontha grub feeding on scots pine roots. Folia Forestalia Polonica A 56:135-140

Słowik-Borowiec M, Szpyrka E, Kurdziel A, Grzegorzak M, Matyaszek A (2012) Assessment of the pesticide residue occurrence in fruit from the south-eastern region of Poland during 2010-2011 seasons. J Fruit Ornam Plant Res 20:119-126

Sukovata L, Jaworski T, Karolewski P, Kolk A (2015) The performance of Melolontha grubs on the roots of various plant species. Turk J Agric For 39:107-116. https://doi.org/10.3906/tar-1405-60

Szpyrka E, Sadło S (2009) Disappearance of azoxystrobin, cyprodinil, and fludioxonil residues on tomato leaves in a greenhouse. J Plant Prot Res 49:204-208

Szpyrka E, Walorczyk S (2013) Dissipation kinetics of fluquinconazole and pyrimethanil residues in apples intended for baby food production. Food Chem 141(4):3525-3530. https://doi.org/10. 1016/j.foodchem.2013.06.055

Szpyrka E, Machowska A, Sadło S (2008) Residues of plant protection products in organic food of plant origin in south-eastern Poland in 2004-2007. J Res Appl Agric Eng 53:101-103

Szpyrka E, Kurdziel A, Matyaszek A, Podbielska M, Rupar J, SłowikBorowiec M (2015) Evaluation of pesticide residues in fruit and vegetables from the region of south-eastern Poland. Food Control 48:137-142. https://doi.org/10.1016/j.foodcont.2014.05.039

Totic I (2014) Raspberry breeding and protection against disease and pests. Bulg J Agric Sci 20:391-404

Valverde-Garcia A, Gonzalez-Pradas E, Aguilera-des Real A (1993) Analysis of buprofezin residues in vegetables. Application to the degradation study on eggplant grown in a greenhouse. J Agric Food Chem 41(12):2319-2323. https://doi.org/10.1021/ jf00036a019

Wyszukiwarka Środków Ochrony Roślin. http://www.minrol.gov.pl/pol/ Informacje-branzowe/Wyszukiwarka-srodkow-ochrony-roslin. Accessed January 2017

Zhang W, Chen H, Han X, Yang Z, Tang M, Zhang J, Zeng S, Hu D, Zhang K (2015) Determination and analysis of the dissipation and residue of cyprodinil and fludioxonil in grape and soil using a modified QuEChERS method. Environ Monit Assess 187(7):414. https://doi.org/10.1007/s10661-015-4661-9 